Gizi Indon 2009, 32(1):77- $89 \quad$ Pengembangan instrumen kemitraan $\quad$ P.A. Kodrat

$P$.

\title{
PENGEMBANGAN INSTRUMEN KEMITRAAN DESA SIAGA DI KABUPATEN SUBANG, JAWA BARAT*)
}

\author{
Peristiwanto Adiyono Kodrat Pramudho ${ }^{1}$ \\ ${ }^{1}$ Pusat Promosi Kesehatan, Departemen Kesehatan R.I.
}

\section{ABSTRACT \\ THE DEVELOPMENT OF PARTNERSHIP INSTRUMENT OF "DESA SIAGA" IN SUBANG DISTRICT, WEST JAVA PROVINCE}

The successful of "Desa Siaga" as one of the forms of Community Based Health Activities (CBHA) depends on, among others, the good partnership of different elements in the community, especially the partnership between health providers with the community. Desa Siaga is a village that has enough human resources, abilities, and willingness to prevent and solve any health problem, disasters and emergencies occurred in the village self reliantly. The objective of this study is to develop the instrument that is able to measure the partnership of Desa Siaga in Indonesia. The study is conducted in Subang District, since this district has been declared as the only district that has 100 percent Desa Siaga in the whole district. The length of study is nine months, starting from February, 2008. The method of study is a mixed paradigm, which is a combination of qualitative and quantitative study methods. The methods of study used in the qualitative study are focus group discussion (FGD), in-depth interview (IDI), and expert meeting. While in the quantitative study is a cross-sectional method. The result of this study were: Firstly, from the literature review it reveals that there are three main variables that are important in partnership, namely openness, equality and mutual benefit. Secondly, from FGD and IDI, these methods are able to elaborate three main variables as mentioned above into 31 detailed variables. Thirdly, result from the expert meeting is the churnedout of the 31 detailed variables into 52 detailed variables. Fourthly, by using factor analysis of the opinions prompted from 172 respondents, we are able to subtract these 52 detailed variables into 17 main variables that are the important to determine the degree of partnership of Desa Siaga. These 17 main variables, then, are to be used as the main variables in the development of instrument to measure the degree of partnership of Desa Siaga. This instrument has been tested in $\mathbf{3 0}$ villages in Subang District. The results are: 17 villages with good partnerships and the remaining 13 with less satisfactory partnerships. If we cross-tabulate the result from the study, it reveals that villages which fall into "good" categorization tend to have good partnership in Desa Siaga.

Keywords: instrument, variable, partnership, desa siaga

*) Bagian dari disertasi

\section{PENDAHULUAN}

$\mathrm{S}$ etiap orang berkewajiban untuk ikut serta dalam memelihara dan meningkatkan derajat kesehatan, karenanya untuk keberhasilan pembangunan kesehatan diperlukan keikut-sertaan dan atau pemberdayaan masyarakat ${ }^{1}$. Pemberdayaan masyarakat adalah segala upaya fasilitasi yang bersifat non-instruktif untuk meningkatkan pengetahuan dan kemampuan masyarakat agar mampu mengidentifikasi masalah, merencanakan, dan melakukan pemecahannya dengan memanfaatkan potensi setempat dan fasilitas yang ada, baik dari instansi lintas sektor maupun LSM dan tokoh masyarakat ${ }^{2}$. Pemberdayaan masyarakat akan menghasilkan kemandiran masyarakat.

Di Indonesia pemberdayaan masyarakat di bidang kesehatan telah lama diterapkan yakni dengan diselenggarakannya pendekatan PKMD (Pembangunan Kesehatan Masyarakat Desa). Bermula di Kabupaten Banjarnegara pada tahun 1976, yang kemudian makin berkembang ketika pada tahun 1978 dideklarasikan Primary Health Care (PHC) sebagai strategi pembangunan kesehatan yang melibatkan masyarakat sebagai subyek. Bahkan pada 
$P$.

era orde baru, pendekatan PKMD ditetapkan sebagai kunci untuk mencapai tujuan pembangunan kesehatan nasional yaitu menjadikan setiap penduduk mampu hidup sehat (Depkes, 1995). Pendekatan PKMD atau disebut juga pendekatan edukatif adalah serangkaian kegiatan yang sistematis, terencana dan terarah untuk menggali, meningkatkan dan mengarahkan keikut-sertaan masyarakat agar dapat memanfaatkan potensi yang ada, guna memecahkan masalah kesehatan yang mereka hadapi ${ }^{3}$.

Pendekatan PKMD diwujudkan dalam berbagai bentuk upaya kesehatan berbasis masyarakat (UKBM) seperti Posyandu, Polindes dan Pos Obat Desa ${ }^{3}$. Untuk mempercepat pencapaian sasaran Indonesia Sehat 2010, Departemen Kesehatan pada tahun 2006 menetapkan visi baru yaitu "masyarakat yang mandiri untuk hidup sehat" dengan misi "membuat rakyat sehat". Sejak tahun 2006 tersebut kebijakan pemberdayaan masyarakat di bidang kesehatan difokuskan pada pembentukan dan pengembangan Desa Siaga sebagai wahana menuju Desa Sehat. Desa Siaga adalah desa yang penduduknya memiliki kesiapan sumberdaya, dan kemampuan serta kemauan untuk mencegah dan mengatasi masalah-masalah kesehatan, bencana dan kegawat-daruratan kesehatan secara mandiri (Kepmenkes No. 564/2006). Peluncuran pembangunan Desa Siaga dilakukan oleh Wakil Presiden RI pada peringatan Hari Kesehatan Nasional ke 42 tahun 2006 di Kabupaten Lumajang Provinsi Jawa Timur, dan hingga pertengahan tahun 2008 telah terbentuk 38.135 Desa Siaga di seluruh Indonesia ${ }^{5}$. Banyak faktor yang berhubungan dengan keberhasilan Desa Siaga yang diukur dengan semakin berdayanya masyarakat di bidang kesehatan yang difasilitasi oleh provider kesehatan. Kemitraan antara provider dan masyarakat adalah salah satu faktor penting dalam mewujudkan Desa Siaga. Peranan masyarakat dalam mewujudkan Desa Siaga sangat besar, sedangkan peranan provider lebih sebagai pendamping masyarakat atau memberikan saran kepada masyarakat dalam bentuk fasilitasi teknis di lapangan.

Pengalaman dalam membangun kemitraan selama ini memerlukan pendekatan edukatif yang bersifat bottom-up. Kemitraan adalah salah satu pilar kesinambungan (sustainability) pemberdayaan masyarakat di bidang kesehatan. Kemitraan dalam mewujudkan Desa Siaga tidak terlepas dari kontribusi berbagai pihak, kemitraan antara pemerintah dan masyarakat, serta antara kelembagaan masyarakat yang ada di desa. Sampai saat ini gambaran kemitraan Desa Siaga belum diketahui, karena instrumen untuk mengukur kemitraan Desa Siaga belum ada.

Penelitian ini bertujuan untuk memperoleh instrumen pengukuran kemitraan Desa Siaga. Secara khusus penelitian ini bertujuan untuk memperoleh:

a. Variabel kemitraan Desa Siaga.

b. Bentuk instrumen pengukur kemitraan Desa Siaga.

\section{BAHAN DAN CARA}

\section{Lokasi Penelitian}

Penelitian dilakukan di Kabupaten Subang Provinsi Jawa Barat, yang menyatakan seratus persen desanya telah menjadi Desa Siaga. Lamanya penelitian selama 9 bulan yang dimulai sejak Februari 2008.

\section{Rancangan Penelitian}

Penelitian ini menggunakan rancangan penelitian mix paradigm metode gabungan yaitu memadukan pendekatan kualitatif dan kuantitatif ${ }^{6}$. Pendekatan kualitatif digunakan untuk membuat permodelan instrumen kemitraan Desa Siaga. Pada pendekatan ini dilakukan eksplorasi kepada masyarakat tentang kemitraan dengan cara fokus group diskusi (FGD), dan wawancara mendalam (WM), serta selanjutnya dibahas dalam pertemuan para ahli (experts meeting) untuk mengintegrasikan konsep dengan kenyataan di lapangan ${ }^{7}$. Data kualitatif yang dikumpulkan difokuskan pada hal-hal penting dalam kemitraan mencakup aspek keterbukaan, aspek kesetaraan dan aspek 
$P$.

manfaat (benefit). Selanjutnya dari data yang terkumpul, dirumuskan untuk kemudian disintesakan menjadi instrumen guna mengukur kemitraan Desa Siaga.

Sedangkan pendekatan kuantitatif digunakan untuk penajaman instrumen yang telah disusun serta memotret dan mengukur derajat kemitraan Desa Siaga. Rancangan penelitian yang digunakan pada pendekatan kuantitatif adalah penelitian potong lintang (cross sectional) baik pada waktu penajaman instrumen maupun memotret dan mengukur derajat kemitraan Desa Siaga.

\section{Pengumpulan, Pengolahan dan Analisis Data}

Penelitian kualitatif dilakukan dengan cara fokus group diskusi, wawancara mendalam, dan pertemuan dengan oleh para ahli/pakar. Informasi yang digali serta FGD dan WM diarahkan untuk membangun konstruksi kemitraan dengan memfokuskan pada hal-hal penting dalam kemitraan mencakup aspek keterbukaan, aspek kesetaraan dan aspek manfaat. Sumber informasi pada FGD terdiri dari 2 (dua) kategori informan yakni kelompok komunitas (kader, tokoh masyarakat, dan aparatur desa), dan kelompok provider kesehatan (Bidan di Desa, dan Petugas Promkes Puskesmas) yang tersebar dari wilayah dataran, pantai dan pegunungan. Jumlah seluruh informan hádala sebanyak 128 orang terdiri dari kelompok provider sebanyak 54 orang, dan kelompok komunitas sebanyak 74 orang yang berasal dari 25 desa. Sumber informasi pada WM adalah 6 (enam) orang informan dengan rincian 3 (tiga) orang Kepala Puskesmas yang masing-masing mewakili wilayah dataran, pegunungan, dan pantai. Sedangkan 3 (tiga) orang lainnya hádala Kepala Subdinas Promosi Kesehatan; Kepala Subdinas Kesehatan Keluarga, dan Kepala Dinas Kesehatan Kabupaten Subang. Dengan komposisi informan seperti ini, maka triangulasi sumber informasi dan metoda dalam penelitian kualitatif ini telah dapat dipenuhi. Temu ahli yang terdiri dari ahli kesehatan masyarakat, psikologi sosial dan sosiologi perdesaan memusatkan pembahasannya pada masalah kemitraan serta konfirmasi dan penguatan konsep dan teori kemitraan berdasarkan kajian literatur dengan hasil FGD dan WM. Hasil analisis data kualitatif digunakan sebagai bahan dalam penyusunan instrumen kemitraan Desa Siaga yang kemudian dibahas oleh ahli/pakar yang dilakukan pada tanggal 6 Juni 2008.

Penelitian kuantitatif dilakukan sebanyak 2 (dua) kali. Pertama, untuk mempertajam instrumen, yang ditujukan terhadap sejumlah responden provider dan komunitas. Kedua, untuk memotret kemitraan Desa Siaga yang ditujukan terhadap sejumlah Desa Siaga. Penelitian menggunakan disain potong lintang (cross sectional), karena disain ini dapat mengukur pelbagai variabel pada satu saat tertentu dengan satu kali observasi saja, yang dalam hal ini adalah pendapat responden terhadap instrumen serta derajat kemitraan Desa Siaga. Populasi penelitian untuk penajaman instrumen adalah seluruh petugas kesehatan yang aktif di 30 Desa Siaga. Ada 3 (tiga) petugas kesehatan untuk setiap Desa Siaga. Karena responden diambil secara berpasangan, maka jumlah seluruh responden untuk penajaman instrumen adalah 6 orang dikali 30 desa atau sebanyak 180 orang, yang dalam penelitian ini berhasil dihubungi hanya sebanyak 172 orang.

Populasi penelitian untuk mengukur kemitraan Desa Siaga adalah seluruh desa yang telah menjadi Desa Siaga di Kabupaten Subang Propinsi Jawa Barat yang berjumlah sebanyak 253 Desa Siaga ${ }^{8}$. Sampel peneltian ini adalah 30 Desa Siaga yang dipilih secara acak. Ditetapkannya jumlah 30 Desa Siaga, karena jumlah ini adalah syarat minimal suatu sampel penelitian. Lima puluh persen (15 desa) dari desa yang terpilih termasuk kelompok desa dengan kondisi baik, dan sisanya (15 desa) termasuk kelompok desa dengan kondisi kurang.

Instrumen penelitian kuantitatif menggunakan instrumen yang berisi variabel kemitraan Desa Siaga berdasarkan hasil temu ahli/pakar. Uji coba telah dilakukan di 2 (dua) desa berbeda yaitu di Kabupaten Bogor, dan di Kabupaten Tangerang. Ujicoba 
P.

instrumen bertujuan untuk memperoleh pemahaman dan kejelasan variabel oleh responden.

Ujicoba instrumen di Kabupaten Bogor dilakukan dengan membacakan pertanyaan kepada responden oleh peneliti. Ada 5 (lima) kelompok responden yang ikut dalam ujicoba yaitu Petugas Promkes Puskesmas, Bidan di Desa, kader kesehatan, fasilitator Desa Siaga, dan aparatur desa.

Uji coba instrumen di Kabupaten Tangerang menggunakan kelompok responden yang sama seperti yang pertama. Perbedaannya adalah responden langsung mengisi sendiri instrumen dengan pendampingan. Perbaikan instrumen sebagai hasil ujicoba di Kabupaten Tangerang ini, dipakai sebagai bahan diskusi pada temu ahli. Selanjutnya dengan koreksi promotor dan ko promotor, instrumen kemitraan Desa Siaga dipakai sebagai instrumen pada penelitian kuantitatif untuk mempertajam instrumen kemitraan Desa Siaga. Sedangkan instrumen pada penelitian kuantitatif untuk memotret dan mengukur kemitraan Desa Siaga adalah instrumen kemitraan Desa Siaga hasil penajaman.

Pengumpulan data kuantitatif dilakukan pada bulan Juni 2008 oleh 7 (tujuh) orang enumerator yang berasal dari staf pengajar Akademi Keperawatan Kabupaten Subang. Para enumerator, sebagian besar berlatar belakang pendidikan pasca sarjana kesehatan dan telah memiliki pengalaman penelitian kuantitatif. Sebelum ke lapangan, mereka dibekali dengan materi tentang maksud dan tujuan penelitian, kerangka konsep penelitian, instrumen yang digunakan, etika penelitian, proses yang akan dilalui mulai dari pengumpulan, pengolahan sampai dengan analisis data.

Editing atau penyuntingan data dilakukan oleh peneliti setiap hari, dan jika terjadi kesalahan atau jawaban kosong, instrumen akan dikembalikan kepada enumerator untuk dilakukan konfirmasi ulang. Selanjutnya data kuantitatif diolah dengan program EPI DATA untuk kemudian dianalisis dengan menggunakan program SPSS. Analisis data seleksi variabel menggunakan metoda statistik Analisis Faktor. Selanjutnya dengan menggunakan matriks derajat kemitraan Desa Siaga menurut provider dan komunitas, dilakukan kesepadanan antara kedua macam responden, sebagaimana tertera pada Tabel 1 di bawah ini.

Tabel 1

Derajat Kemitraan Desa Siaga dengan Penilaiannya

\begin{tabular}{|c|c|c|c|}
\hline Kemitraan & Provider & Komunitas & Nilai \\
\hline \multirow{4}{*}{ Keterbukaan } & Setuju (+) & Setuju (+) & 2 \\
\hline & Setuju (+) & Tidak setuju (-) & \\
\hline & Tidak setuju (-) & Setuju (+) & 1 \\
\hline & Tidak setuju (-) & Tidak setuju (-) & 0 \\
\hline \multirow{4}{*}{ Kesetaraan } & Setuju (+) & Setuju (+) & 2 \\
\hline & Setuju (+) & Tidak setuju (-) & 1 \\
\hline & Tidak setuju (-) & Setuju (+) & 1 \\
\hline & Tidak setuju (-) & Tidak setuju (-) & 0 \\
\hline \multirow{4}{*}{ Manfaat/benefit } & Setuju (+) & Setuju (+) & 2 \\
\hline & Setuju (+) & Tidak setuju (-) & 1 \\
\hline & Tidak setuju (-) & Setuju (+) & 1 \\
\hline & Tidak setuju (-) & Tidak setuju (-) & 0 \\
\hline
\end{tabular}

Analisis univariat dilakukan untuk mengetahui distribusi pendapat masyarakat terhadap variabel kemitraan Desa Siaga yang disusun dalam bentuk tabel. Analisis 
P.

bivariat dilakukan untuk mengetahui derajat kemitraan serta hubungan antara variabel kemitraan Desa Siaga dengan pencapaiaan cakupan Desa Siaga. Analisis derajat kemitraan Desa Siaga dilakukan sebagai berikut:

a. Unit analisis adalah desa

b. Sub unit analisis adalah 4 orang responden dari tiap desa, yang terdiri dari 2 orang provider kesehatan, dan 2 orang unsur masyarakat/komunitas

c. Pemberian nilai bobot: Jawaban provider (ya) dan jawaban komunitas (ya) = nilai 2

Jawaban provider (ya) dan jawaban komunitas (tidak) $=$ nilai 1

Jawaban provider (tidak) dan jawaban komunitas (ya) = nilai 1

Jawaban provider (tidak) dan jawaban komunitas $($ tidak) $=$ nilai 0

d. Penentuan tingkatan kemitraan baik atau kurang, berdasarkan titik potong (cut of point) nilai rata-rata atau nilai mean.

Analisis multivariat sesuai dengan tujuan penelitian yakni memilih variabel yang paling sesuai untuk mengukur kemitraan Desa Siaga, mengunakan analisis faktor (factor analysis). Pada analisis faktor ini dipergunakan metode PCA (Principal Component Analysis) atau analisis komponen utama. Metode ini mentransformasi himpunan variabel ke dalam sebuah himpunan baru yang berisi variabel majemuk atau komponen utama yang tidak saling berkorelasi dengan yang lainnya.

HASIL

\section{Hasil Penelitian Kualitatif}

Penelitian kualitatif dengan metode FGD dan WM mencatat 31 variabel kemitraan sebagaimana dapat dilihat pada tabel di bawah ini.

Tabel 2

Variabel Kemitraan Hasil FGD dan WM

No Variabel Kemitraan

Komponen Keterbukaan

1. Keterbukaan pengelolaan dana oleh aparatur

2. Keterbukaan informasi program Desa Siaga secara menyeluruh

3. Besarnya iuran merupakan kesepakatan antara Kades, Toma dan masyarakat

4. Kesepakatan jumlah uang yang diterima dukun bayi dari bidan

5. Kejelasan penggunaan dana sosial bersalin (dasolin)

6. Keterbukaan sumberdaya dimiliki

7. Kesepakatan siapa melakukan apa dalam penanganan kasus risti

8. Pembagian hasil pembayaran antara kemitraan dukun bayi dan bidan

9. Keterbukaan dalam penanganan kasus oleh bidan

10. Keterbukaan informasi Desa Siaga dalam forum masyarakat

11. Keterbukaan masalah yang disampaikan masyarakat kepada petugas

\section{Komponen Kesetaraan}

12. Kesepakatan kepengurusan Desa Siaga berasal dari masyarakat

13. Keputusan pelaksanaan program Desa Siaga harus melibatkan Toma, kader, Kades, 
aparatur desa, bidan di desa dan badan perwakilan desa (BPD)

14. Kesetaraan antara kedudukan Puskesmas dan masyarakat dalam pembahasan pelaksanaan Desa Siaga

15. Tidak ada unsur keterpaksaan dalam bermitra

16. Kedudukan yang sama, tidak menggurui satu sama lain antara petugas dan masyarakat

17. Membangun kepercayaan dan saling membutuhkan

18. Masyarakat bukan bawahan tetapi sebagai mitra

19. Puskesmas sebagai fasilitator, keputusan bersama dalam forum desa

20. Kesepakatan penentuan tarif bidan melibatkaan unsur masyarakat

21. Mempunyai hak yang sama dalam menyusun rencana dan pelaksanaan

Komponen Manfaat

22. Meningkatnya pengetahuan Kader tentang kesehatan yang berpengaruh pada sikap dan perilakunya

23. Kepercayaan masyarakat memudahkan aparat dalam menjalankan suatu program di desa

24. Masyarakat merasakan manfaat dari Dasolin dan sistem rujukan kasus maternal, sehingga mau percaya dan berpartisipasi aktif

25. Meningkatnya pengetahuan dukun paraji dan merasa terbantu jika menangani persalinan sulit, dan mulai percaya dengan bidan

26. Dukun paraji mulai banyak melaporkan data ibu hamil kepada bidan

27. Semakin banyak ibu yang melahirkan dengan bidan

28. Puskesmas merasa untung dengan kerjasama lintas sektor dengan kecamatan

29. Pemberian bantuan oleh Puskesmas, meningkatkan partisipasi masyarakat dalam program kesehatan

30. Masyarakat sudah merasakan keuntungan dari Dasolin dan Tabulin

31. Meningkatnya pengetahuan masyarakat melalui penyuluhan seiring dengan tingkat partisipasi masyarakat dalam pelaksanaan program

\section{Hasil Temu Ahli}

Masukan para ahli pada prinsipnya tidak bertentangan dengan hasil FGD dan WM, bahkan memperkuat serta mempertajam beberapa varaiabel. Hasil temu ahli yang penting adalah bahwa keterbukaan sejajar dengan input, kesetaraan sejajar dengan proses, dan manfaat sejajar dengan output dalam manajemen.

Hasil temu ahli mencatat 52 variabel kemitraan yang terdiri dari komponen keterbukaan sebanyak 12 variabel $(23,1 \%)$, komponen kesetaraan sebanyak 26 variabel $(50,0 \%)$, serta komponen manfaat sebanyak 14 variabel $(26,9 \%)$. Rincian selengkapnya dapat dilihat tabel di bawah ini. 
Tabel 3

Variabel Kemitraan Hasil Temu Ahli

\begin{tabular}{ll}
\hline No. Komponen & \multicolumn{1}{c}{ Variabel } \\
\hline A. Keterbukaan & 1. Sumber dana \\
& 2. Jumlah dana \\
3. Pemanfaatan dana & 4. Pertanggungan jawab dana \\
5. Pihak-pihak yang terlibat \\
6. Jumlah tenaga yang terlibat \\
7. Peran dan tanggung jawab dana \\
8. Kewenangan masing-masing \\
9. Imbal jasa \\
10. Rincian sarana \\
11. Pemanfaatan sarana \\
12. Pertanggung-jawaban sarana \\
13. Status dan kedudukan \\
14. Menetapkan masalah \\
15. Merumuskan tujuan kegiatan \\
16. Menetapkan kegiatan \\
17. Menentukan pelaksana \\
18. Menentukan sarana kegiatan \\
19. Hak suara \\
20. Hak bicara \\
21. Status \& kedudukan yang sama \\
22. Tanggung jawab sama \\
23. Peran yang sama \\
24. Menentukan besarnya dana swadaya \\
25. Pengaturan peran (koordinasi) \\
26. Memperoleh Penghargaan yang sama \\
27. Sangsi yang sama \\
28. Bersiaga dan siap digunakan \\
29. Kedudukan dan status yang sama \\
30. Menetapkan ukuran/kriteria penilaian \\
K.
\end{tabular}


31. Merumuskan tujuan

32. Menentukan cara penilaian

33. Menentukan pelaksanaan penilaian

34. Menentukan sarana/alat penilai

35. Memiliki hak suara

36. Menyampaikan protes/ketidak-puasan

37. Menentukan tingkat keberhasilan

38. Menentukan tingkatan keeberhasilan

C. Manfaat (Benefit)

39. Meringankan pekerjaan petugas kesehatan

40. Membantu percepatan pencapaian tujuan

41. Memperluan hubungan kerjasama

42. Meningkatkan pengetahuan \& ketrampilan

43. Meningkatkan kemandirian masyarakat

44. Meningkatkan penghasilan masyarakat

45. Meningkatkan penghasilan keluarga

46. Meningkatkan perekonomian desa

47. Masyarakat lebih sejahtera

48. Pengakuan dan penghargaan

49. Membuat masyarakat lebih peduli

50. Membuat masyarakat lebih tanggap

51. Menurunkan angka kesakitan

52. Meningkatkan derajat kesehatan

\section{Hasil Penelitian Kuantitatif Penajaman Instrumen}

Penelitian kuantitatif untuk penajaman 52 variabel kemitraan Desa Siaga menggunakan disain potong lintang (cross sectional). Dengan jumlah responden sebanyak 172 orang, terdiri dari reponden kelompok komunitas (kader, tokoh masyarakat, dan aparatur desa) sebanyak 90 orang $(52,3 \%)$, dan rsponden kelompok provider (bidan di desa, perawat desa, dan dokter/bidan/petugas Promkes Puskesmas) sebanyak 82 orang (47,7\%). Reponden perempuan ditemukan sebanyak 95 orang $(55,2 \%)$ dan laki-laki sebanyak 77 orang $(44,8 \%)$.

Semua variabel kemitraan Desa Siaga kemudian ditanya persetujuannya terhadap 172 responden, dengan menggunakan jawaban skala 1-10, responden dianggap setuju bila memberikan nilai antara 6-10, dan tidak setuju bila memberikan nilai 1-5. Hasil yang diperoleh untuk variabel keterbukaan, kesetaraan dan manfat dapat dilihat pada tabel berikut ini. 
$P$.

Tabel 4

Pendapat Responden terhadap Variabel Keterbukaan $(n=172)$

\begin{tabular}{lcc}
\hline \multicolumn{1}{c}{ Variabel } & Setuju & Tidak Setuju \\
\cline { 2 - 3 } & $\mathrm{n}$ & $\mathrm{n}$ \\
\hline 1. Sumber dana & $99(57,6 \%)$ & $73(42,4 \%)$ \\
2. Jumlah dana & $88(51,2 \%)$ & $84(48,8 \%)$ \\
3. Pemanfaatan dana & $105(61,0 \%)$ & $67(39,0 \%)$ \\
4. Pertanggungan jawab dana & $95(55,2 \%$ & $77(44,8 \%)$ \\
5. Pihak-pihak yang terlibat & $115(66,9 \%)$ & $57(33,1 \%)$ \\
6. Jumlah tenaga yang terlibat & $111(64,5 \%)$ & $61(35,5 \%)$ \\
7. Peran dan tanggung jawab dana & $110(64,0 \%)$ & $62(36,0 \%)$ \\
8. Kewenangan masing-masing & $99(57,6 \%)$ & $73(42,4 \%)$ \\
9. Imbal jasa & $84(48,8 \%)$ & $88(51,2 \%)$ \\
10. Rincian sarana & $98(57,0 \%)$ & $74(43,0 \%)$ \\
11. Pemanfaatan sarana & $100(58,1 \%)$ & $72(41,9 \%)$ \\
12. Pertanggung-jawaban sarana & $103(59,9 \%)$ & $69(40,1 \%)$ \\
\hline \multicolumn{1}{c}{ Setuju = nilai 6 -10 } & Tidak setuju = nilai $1-5$ &
\end{tabular}

Tabel 4 menunjukkan bahwa hampir seluruh variabel mendapatkan persetujuan dari responden dengan nilai di atas 57

persen, kecuali untuk variabel imbal jasa yang hanya memperoleh nilai kurang dari 50 persen $(48,8 \%)$.

Tabel 5

Pendapat Responden terhadap Variabel Kesetaraan $(n=172)$

\begin{tabular}{lcc}
\hline \multirow{2}{*}{ Variabel } & Setuju & Tidak Setuju \\
\cline { 2 - 3 } & $\mathrm{n}$ & $\mathrm{n}$ \\
\hline 1. Status dan kedudukan & $100(58,1 \%)$ & $72(41,9 \%)$ \\
2. Menetapkan masalah & $110(64,0 \%)$ & $62(36,0 \%)$ \\
3. Merumuskan tujuan kegiatan & $114(66,3 \%)$ & $58(33,7 \%)$ \\
4. Menetapkan kegiatan & $115(66,9 \%)$ & $57(33,1 \%)$ \\
5. Menentukan pelaksana & $115(66,9 \%)$ & $57(33,1 \%)$ \\
6. Menentukan sarana kegiatan & $81(47,1 \%)$ & $91(52,9 \%)$ \\
7. Hak suara & $63(36,6 \%)$ & $109(63,4 \%)$ \\
8. Hak bicara & $66(38,4 \%)$ & $106(61,6 \%)$ \\
9. Status \& kedudukan yang sama & $112(65,1 \%)$ & $60(34,9 \%)$ \\
10. Tanggung jawab sama & $115(66,9 \%)$ & $57(33,1 \%)$ \\
11. Peran yang sama & $99(57,6 \%)$ & $73(42,4 \%)$ \\
12. Menentukan besarnya dana swadaya & $110(64,0 \%)$ & $62(36,0 \%)$
\end{tabular}


P.

\begin{tabular}{lll} 
13. Pengaturan peran (koordinasi) & $96(55,8 \%)$ & $76(44,2 \%)$ \\
14. Memperoleh Penghargaan yang sama & $87(50,6 \%)$ & $85(49,4 \%)$ \\
15. Sangsi yang sama & $84(48,8 \%)$ & $88(51,2 \%)$ \\
16. Bersiaga dan siap digunakan & $63(36,6 \%)$ & $109(63,4 \%)$ \\
17. Kedudukan dan status yang sama & $91(52,9 \%)$ & $81(47,1 \%)$ \\
18. Menetapkan ukuran/kriteria penilaian & $88(51,2 \%)$ & $84(48,8 \%)$ \\
19. Merumuskan tujuan penilaian & $90(52,3 \%)$ & $82(47,7 \%)$ \\
20. Menentukan cara penilaian & $90(52,3 \%)$ & $82(47,7 \%)$ \\
21. Menentukan pelaksanaan penilaian & $84(48,8 \%)$ & $88(51,2 \%)$ \\
22. Menentukan pelaksanaan penilaian & $84(48,8 \%)$ & $88(51,2 \%)$ \\
23. Menentukan sarana/alat penilaian & $83(48,3 \%)$ & $80(46,5 \%)$ \\
24. Memiliki hak suara dalam penilaian & $91(52,9 \%)$ & $81(47,1 \%)$ \\
25. Menyampaikan protes/ketidak-puasan & $66(38,4 \%)$ & $106(61,6 \%)$ \\
26. Menentukan tingkat keberhasilan & $99(57,6 \%)$ & $73(42,4 \%)$ \\
\hline
\end{tabular}

Setuju $=$ nilai $6-10 \quad$ Tidak setuju $=$ nilai $1-5$

Tabel 5 menunjukkan dari 26 variabel kesetaraan ada 9 variabel yang memiliki nilai

di bawah 50 persen, dan sisanya 17 variabel memiliki nilai lebih dari 50 persen.

Tabel 6

Pendapat Responden terhadap Variabel Manfaat

\begin{tabular}{lcc}
\hline \multirow{1}{*}{ Variabel } & Setuju & Tidak Setuju \\
\cline { 2 - 3 } & $\mathrm{n}$ & $\mathrm{n}$ \\
\hline 1. Meringankan pekerjaan petugas kesehatan & $64(37,2 \%)$ & $108(62,8 \%)$ \\
2. Membantu percepatan pencapaian tujuan & $108(62,8)$ & $64(37,2 \%)$ \\
3. Memperluan hubungan kerjasama & $100(58,15)$ & $72(41,9 \%)$ \\
4. Meningkatkan pengetahuan \& ketrampilan & $112(65,1 \%)$ & $60(34,9 \%)$ \\
5. Meningkatkan kemandirian masyarakat & $95(55,2 \%)$ & $77(44,8 \%)$ \\
6. Meningkatkan penghasilan masyarakat & $105(61,0 \%)$ & $67(39,0 \%)$ \\
7. Meningkatkan penghasilan keluarga & $73(42,4 \%)$ & $99(57,6 \%)$ \\
8. Meningkatkan perekonomian desa & $82(47,7 \%)$ & $90(52,3 \%)$ \\
9. Masyarakat lebih sejahtera & $93(54,1 \%)$ & $79(45,9 \%)$ \\
10. Pengakuan dan penghargaan & $96(55,8 \%)$ & $76(44.2 \%)$ \\
11. Membuat masyarakat lebih peduli & $115(66,9 \%)$ & $57(33,1 \%)$ \\
12. Membuat masyarakat lebih tanggap & $95(55,2 \%)$ & $77(44,8 \%)$ \\
13. Menurunkan angka kesakitan & $66(38,45)$ & $106(61,65)$ \\
14. Meningkatkan derajat kesehatan & $61(35,5 \%)$ & $111(64,5 \%)$ \\
\hline Setuju = nilai 6 -10 & Tidak setuju = nilai 1 - 5 &
\end{tabular}


$P$.

Tabel 6 menunjukkan bahwa dari 14 variabel manfaat dalam kemitraan, yang mendapatkan persetujuan dari responden sebanyak 9 variabel dengan nilai lebih 50 persen, sedangkan sisanya sebanyak 5 variabel hanya mendapatkan nilai di bawah 50 persen. Temuan hasil di atas selanjutnya dianalisis dengan menggunakan analisis faktor, melalui 5 (lima) tahap sebagaimana gambar di bawah ini.

\section{Gambar 1}

Alur Analisis Faktor \& Validasi

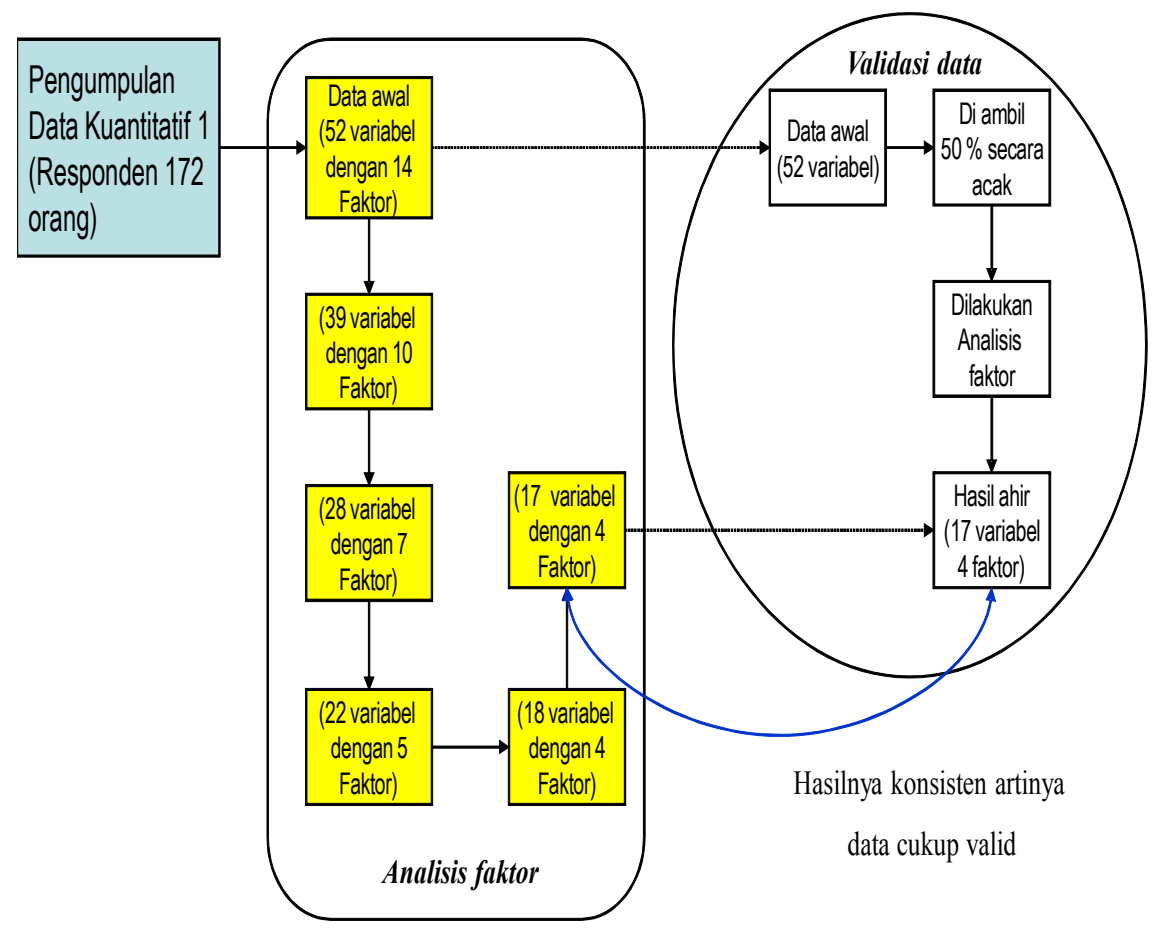

Hasil akhir diperoleh 4 (empat) faktor dengan 17 variabel yang terdiri dari faktor manfaat sebanyak 7 variabel $(41,2 \%)$, faktor kesetaraan eksternal 4 variabel $(23,5 \%)$, faktor keterbukaan sebanyak 4 variabel $(23,5$ $\%)$, dan faktor kesetaraan internal sebanyak 2 variabel $(11,8 \%)$. Rincian selengkapnya dapat dilihat pada tabel berikut ini.

Tabel 7

Hasil Akhir Analisis Faktor

\begin{tabular}{lll}
\hline Faktor & & \\
\hline Manfaat & 1. & meningkatkan kemandirian masyarakat di bidang kesehatan \\
& 2. & meningkatkan penghasilan keluarga \\
& 3. & meningkatkan perekonomian masyarakat desa \\
& 4. & menjadikan masyarakat lebih sejahtera \\
& 5. & meningkatkan citra dari pihak lain \\
\hline
\end{tabular}


$P$.

6. meningkatkan penghasilan masyarakat desa

7. lebih peduli terhadap masalah kesehatan

\begin{tabular}{lll}
\hline & 1. & masyarakat ikut serta dalam merumuskan tujuan kegiatan \\
Kesetaraan & 2. & mempunyai peran yang sama \\
Eksternal & 3. & memperoleh penghargaan yang sama \\
& 4. & menentukan pelaksana penilaian
\end{tabular}

\begin{tabular}{lll}
\hline & 1. & tersedia informasi tentang jumlah dana \\
& 2. & tersedia informasi yang mudah diminta tentang pertanggung-jawaban \\
Keterbukaan & dana & tersedia informasi tentang kewenangan masing-masing pihak yang \\
& 3. & terlibat \\
& 4. $\quad$ tersedia informasi tentang imbal jasa yang diterima
\end{tabular}

Kesetaraan 1. memiliki hak suara (hak untuk dipilih)

Internal 2 . bersiaga dan siap digunakan selama 24 jam

Faktor kesetaraan mengelompok menjadi dua kelompok. Pertama diberi nama kesetaraan external, karena lebih terkait dengan pihak luar. Kelompok kedua diberi nama kesetaraan internal, karena lebih menujuk pada masing-masing diri pribadi.

\section{SIMPULAN}

1. Hasil kajian literatur mencatat konsep kemitraan Desa Siaga mencakup tiga variabel utama yakni keterbukaan, kesetaraan dan manfaat (benefit).

2. Hasil FGD dan WM berhasil menguraikan tiga faktor utama kemitraan menjadi 31 variabel kemitraan Desa Siaga dengan rincian 11 variabel faktor keterbukaan, 10 variabel faktor kesetaraan, dan 10 variabel faktor manfaat.

3. Temu ahli berhasil mengembangkan menjadi 52 variabel kemitraan Desa Siaga dengan rincian 12 variabel faktor keterbukaan, 26 variabel faktor kesetaraan, dan 14 variabel faktor manfaat.

\section{SARAN}

1. Bagi Dinas Kesehatan Kabupaten Subang, diharapkan dapat melakukan pemetaan tentang kemitraan Desa Siaga dengan menggunakan instrumen yang telah dihasilkan dari penelitian ini, sebagai pelengkap instrumen stratifikasi Desa Siaga Gotong Royong yang sudah ada. Dengan demikian, intervensi pembinaan terhadap Desa Siaga akan lebih komprehensif.

2. Bagi Departemen Kesehatan, hendaknya temuan instrument pengukuran kemitraan Desa Siaga dari penelitian ini dapat dipertimbangkan untuk diintegrasikan ke dalam indikator penilaian Desa Siaga yang telah digunakan selama ini.

3. Bagi masyarakat, diharapkan dengan diketahuinya kemitraan Desa Siaga, dapat lebih memacu peningkatan kontribusinya dalam mewujudkan masyarakat yang peduli, dan tanggap terhadap 
$P$.

$$
\begin{aligned}
& \text { masalah kesehatan di wilayah } \\
& \text { masing-masing. }
\end{aligned}
$$

\section{RUJUKAN}

1. Departemen Kesehatan RI, Sistem Kesehatan Nasional, Jakarta, 2004

2. Pemerintah RI dan UNICEF. Panduan Umum Pemberdayaan Masyarakat di Bidang Kesehatan Ibu dan Anak, Jakarta, 1999.

3. Departemen Kesehatan RI. ARRIF: Manajemen Peran Serta Masyarakat, Jakarta, 2001.

4. 4.Departemen Kesehatan RI, Rencana Strategis Departemen Kesehatan tahun 2005-2009, Jakarta, 2006
5. Departemen Kesehatan RI. Profil Kesehatan Indonesia Tahun 2004, Jakarta, 2006.

6. Ariawan, Iwan. Besar dan Metode Sampel pada Penelitian Kesehatan, Jurusan Biostatistik dan Kependudukan FKMUI, Depok, 1998

7. Bungin, Burhan, Metodologi Penelitian Kualitatif, PT Raja grafindo Persada, Jakarta, 2001.

8. Dinas Kesehatan Kabupaten Subang. Profil Kesehatan Kabupaten Subang tahun 2006, Subang, 2007. 